\title{
Kierkegaard and the Knowledge of God
}

\author{
Valentin-Petru Teodorescu
}

\begin{abstract}
Contrary to the common opinion that Kierkegaard is a fideist, there are in fact good proofs that he offers arguments (of an ethical and existential nature) in favor of the belief in God's existence. However, this type of philosophical justification is not classical. Evaluated through the categories of modern epistemology it may be called rather externalist than internalist. The advantage of this approach to the problem of the arguments for God's existence is its egalitarian, eliberating and formative consequences. In addition to that, a result of this view on the belief in God (and the knowledge of his attributes) is the fact that they do not seem to depend in any way by the contingent developments of science or society; therefore, they cannot be affected and eventually deteriorated by these factors.

KEY WORDS: fideism, arguments, knowledge, externalism, egalitarianism, future
\end{abstract}

The theme of this essay is the knowledge of God-more precisely the knowledge that God exists and that he is a certain kind of being-from a Kierkegaardian perspective. There is generally, regarding Kierkegaard, the public perception that he is a fideist, a person for whom belief in God has no rational grounds; from this perspective a theist, in order to adhere to his own metaphysical worldview, needs to make an irrational jump toward faith. The present article suggests that this perception is false. In what follows we shall see that in the support of theistic belief Kierkegaard brings ethical and existential arguments, relating in this way our knowledge 
of God to these universal components of the human subjective experience.

\section{Kierkegaard and the Subjective Knowledge}

The knowledge of God has for Kierkegaard strong ties to our subjectivity; therefore it is important to understand how Kierkegaard understands this last concept. According to Hermann Deuser, Kierkegaard's concept of subjectivity was an answer to a problem raised by the idealist philosophy-which, centering on such elements as 'res cogitans', 'transcendental apperception' and 'the unity of subject and object,' "missed-and, even more than that, positively ignored-the human being in her concrete subjectivity."1But what means to understand the humans in their real subjectivity? What follows offers an answer to this problem.

\subsection{The Knowledge that God Exists; the Subjective Immanent Metaphysical Knowledge}

For Kierkegaard the knowledge that God exists is somehow, "built in our human consciousness" - as Marilyn Piety puts it. ${ }^{2}$ Thus, in a well-known passage from Concluding Unscientific Postscript, he writes:

To demonstrate the existence [Tilvær] of someone who exists [er til] is the most shameless assault, since it is an attempt to make him ludicrous, but the trouble is that one does not even suspect this, that in dead seriousness one regards it as a godly undertaking. How could it occur to anyone to demonstrate that he exists unless one has allowed oneself to ignore him; and now one does it in an even more lunatic way by demonstrating his existence right in front of his nose. ${ }^{3}$

In "Philosophical Fragments" he says that this knowledge, like the truths of mathematics, is gained, in good Socratic (or platonic) fashion, through recollection: 
One does not have faith that god exists [er til], eternally understood, even though one assumes that the god exist. That is an improper use of language. Socrates did not have faith that the god existed. What he knew about the god he achieved through recollection, and for him the existence of the god was by no means something historical. ${ }^{4}$

Even if a person is not able to demonstrate the claim that God exists, this does not seem to deter her from the conviction that this statement corresponds to reality. For Kierkegaard real atheists do not exist. ${ }^{5}$

But how do we obtain this kind of knowledge (or belief) about God? Through a person's wishing to be convinced by it-says Kierkegaard. There are nevertheless some people who do not want to allow this knowledge to control their minds; this explains-at least in part-why belief in the existence of God is not shared by all people ${ }^{6}$. In his book Kierkegaard's Analysis of Radical Evil, David Roberts offers details regarding this process of obscuring and denying the knowledge of God's existence (and the duty related to it) in the Kierkegaardian writings. ${ }^{7}$ We can now understand why knowledge about God's existence is part of subjective knowledge: it has the capacity to control the person who possesses it: in other words, it is related to the existence of the subject.

This knowledge of God is for Kierkegaard part of what he calls the immanent metaphysical knowledge, that kind of knowledge which is for him the subject of the Socratic recollection. This knowledge incorporates the objective knowledge in a strict sense (which referred in his view to such domains as mathematics and ontology/logic), but it is not reduced to these two areas of objective knowledge-which are indifferent to the existence of the concrete individual: ${ }^{2}$ it also includes a subjective side (related to the existence of the individual), which incorporates the knowledge of the existence of God, the knowledge that each individual has a soul, and the knowledge that there are eternally valid norms for human behavior. ${ }^{9}$ 
In this sense Kierkegaard says that: "With respect to the existence of God, immortality, etc., in short, with respect to all problems of immanence, recollection applies; it exists altogether in every man, only he does not know it, but it again follows that the conception may be inadequate" (JP, 3606) p. 3.662 (V.B.40.) He is here in agreement with Karl Barth, who suggested-more than a century after Kierkegaard-that a conception of deity and an obligation to fulfill the moral law are the basic forms of religion, constituting, more or less, universal features of human existence. ${ }^{10}$

But why does Kierkegaard call this knowledge of God immanent metaphysical knowledge?

It is immanent because it is somehow part of the content of human consciousness. It is also subjective because it refers (and is interested) in the human existence, the own existence of the thinking subject. Because this is a "subjective knowledge proper ... it is associated by Kierkegaard with psychological certainty" writes Piety. Moreover, because all subjective knowledge is for him prescriptive, it follows that "the certainty of the knower that a given mental representation corresponds to reality will . . . be inexorably intertwined with his appreciation of his subjective necessity of the correspondence of his existence to the substance of this representation." ${ }^{11}$ As we shall see in the next section, the knowledge that there is a God is-for example-deeply connected with the impression of a (moral) obligation related to Him. ${ }^{12}$

In the case of this immanent knowledge of God, Kierkegaard argues that all people have a subjective conviction that they have a duty to God. An individual always possesses an impression of this duty, even if he, in Piety's words, "is engaged in the activity of obscuring it from himself." 13 The assurance regarding God's existence is for a person proportional to the measure in which she agrees that her life should correspond to God's laws. However, even if her life is not in agreement to God's laws, that person might still be sure that God exists, because-though she fails to do God's will-she might feel guilty for her failure; if this is the case, her guilt represents in fact an agreement "with the reality of this duty" (which may in fact be "the first step down the path of the fulfillment of the duty.) ${ }^{14}$ 


\section{The Knowledge That God Exists and its Relationship with Ethics}

A preliminary conclusion to what we presented until now is that for Kierkegaard "the knowledge that God exists" (the belief in God) functions more or less as a kind of sensus divinitatis, an apriori conviction which appears to be common to all people-although many of them might somehow obscure it, being unwilling to let it get control over their minds. The difference in recognizing or accepting the idea of God's existence is related for Kierkegaard to the way in which people relate to their moral duty (which seems to be associated-or bound-to this belief in God.) The present section intends to focus on this relationship.

\subsection{The Belief in God for the Ethicist and the Religious: Their Relationship with the Ethical Norms}

In Kierkegaaard's view the belief in God is not proper only to what he calls the religious stage of existence-as one might expect. On the contrary, the ethicist (the person who chose to live in the ethical stage of existence-a stage in which morality has priority over all other aspects of human life) believes in God too. To Kierkegaardaccording to Stephen Evans-was alien the idea that ethical life is "free from risky metaphysical commitments, a kind of humanistic stance that does not require belief in God...The ethicists of Kierkegaard are invariably devout and pious individuals who believe in God and participate in the life of the church.... Kierkegaard's ethicists see their ethical duties as divine commandments."15 So, in this respect they do not differ from the religious people in what regards their belief in God (although, as we shall see, to see ethical duties as divine commandments means not that the ethicists will necessary believe in the personal God of monotheism; some of them might just say: "there ought to be a God," a reference to the idea that-for them-the ethical imperatives have power; and this although they might still not yet believe in God. ${ }^{16}$ ) 
The main difference between the ethicist and the religious person refers rather to their confidence in the capacity of fulfilling the ethical task given by God. The ethicists have the confidence that they can by themselves fulfill this task. By contrast, the religious people believe that these demands of the ethical life cannot be fulfilled through their own efforts. They know that there is a gap "between what ethics requires and what human choice can achieve." 17

Therefore, for the ethicist the relation with God is not seen as individual and personal - rather the demands of God are seen as general rules. In this context any duty is a duty to God. However, according to Kierkegaard, "if no more can be said than this, then it is also said that I actually have no duty to God." ${ }^{18}$ By contrasts, the religious person is aware that she is incapable of being what she ought to be-through his own ethical effort. He seeks to determine "his relation to the universal [the ethical] by his relation to the absolute [God], not his relation to the absolute by his relation to the universal."19 This person, says Evans, "has a personal relation to God; he takes as his model the biblical Abraham, who was justified not by ethical deeds but by faith, an attitude of personal trust in God." ${ }^{20}$ In any case, it is important, when thinking to belief in the existence of God, to see that both the ethicist and the religious believe in God and try to respect His ethical norms.

\section{Inwardness and Gaining the Belief in God}

Belief in God is for Kierkegaard intimately bound with taking into account His ethical absolutes-and this attitude is present in both ethical and religious stages, being related to the life of subjectivity and the presence of inwardness into an individual. A genuine moral life starts when the individual understands that he is not totally defined by his social obligations (the Hegelian Sittlichkeit), but rather that he has an absolute ethical task which raises him above the social conformism. When the human being meets this ethical absolute, he meets in fact God. ${ }^{21}$ Climacus actually seems to identify 
God with the ethical (in the experience of inwardness), ${ }^{22}$ at various points:

The direct relationship with God is simply paganism, and only when the break has taken place, only then can there be a true God relationship. But this break is indeed the first act of inwardness oriented to the definition that truth is inwardness. Nature is certainly the work of God, but only the work is directly present, not God. With regard to individual human being, is this not acting like an illusive author, who nowhere sets forth his result in block letters or provides it beforehand in a preface? And why is God illusive? Precisely because he is truth and being illusive seeks to keep a person from untruth. The observer does not glide directly to the result but on his own must concern himself with finding it and thereby break the direct relation. But this break is the actual breakthrough of inwardness, an act of self-activity, the first designation of truth as inwardness. ${ }^{23}$

In other place-referring again to the deep relationship between the ethical and the belief in God-Kierkegaard affirms that freedom is like the lamp of Alladin: "When a person rubs it with ethical passion, God comes into existence for him." 24 (Here, observes M. Westphal, "ethics is the presupposition of religion. In the ontological order, God comes first; in the transcendental order, the ethical is prior. Together they define the domain of subjectivity." $)^{25}$

\subsection{How Inwardness Works: Triggering Factors for Gaining the Belief in God}

However, some commentators observed that although for Kierkegaard living in the ethical stage (for example) leads to a conviction in the existence of God, this does not mean that the people who live ethically are necessarily aware of this divine reality. In this respect Evans writes: 
... though an encounter with the ethical is an encounter with God, it is by no means always the case that the ethical individual recognizes this fact. On the contrary, a person may gain an impression of 'the infinitude of the ethical' without realizing that this involves an impression of God. ${ }^{26}$

M. Piety also suggests that it is possible that a person should be uncertain of God's existence, but in spite of that to have:

... a relatively well-defined idea of what kind of behavior God, if he existed, would require of people and to feel such a strong obligation to conform his behavior to what he imagines would be these requirements that he would say something of the order of 'there ought to be a God', even if it turned out there was not one. ${ }^{27}$

However, is there not a contradiction between the idea that one could feel the infinitude of the ethical imperative (in other words, should live in the ethical stage) and the fact that he might not believe in God-given the previous assertion that the belief in God characterizes the ethical stage?

Our answer to this problem is that, even if this contradiction might be real, it is not very significant for our subject, due to the fact that the ethical stage-if we understand it as a sphere of existence in which we are called to obey a divine task which raises us above the social conformism-it is rather a transitory stage between the two others (aesthetic and religious), lacking stability.

We will better understand why this is so by looking closer to the way in which subjectivity could trigger belief in the existence of God. In what follows will be presented two different perspectives on this subject-which at the first sight might seem contradictorybut which (at a closer look) might prove to be complementary.

\subsubsection{Heiko Schulz: Existential Despair as Triggering Factor}

The first perspective is that of Heiko Schulz, who suggests that for Kierkegaard belief in God represents the pragmatic postulate of a 
person who wants to escape her state of despair. Schulz affirms that "from the perspective of someone experiencing a severe spiritual crisis God may indeed appear as a 'postulate', but not in the loose [viz. Kantian] sense in which it is ordinary taken." ${ }^{28}$ Instead, he quotes Kierkegaard, who writes that "passion . . . assists (that human) in grasping God with the 'category of despair' (faith), so that the postulate, far from being the arbitrary, is in fact necessary defense .... self-defense; in this way God is not a postulate, but the existing person's postulating of God is-a necessity." ${ }^{29} \mathrm{H}$. Schulz also suggests the way in which this pragmatically justified conversion (toward a belief in God) is related to the starting of accepting (and acting according to) certain ethical standards:

Now, if the purportedly desirable consequences of adopting the new worldview also call for the willingness, on the part of convert, to accept and act according to certain ethical standards of conduct - as it is the case with many religions - then he is only justified in claiming that what he pretends to have converted to is in fact the world-view in question, if and inasmuch as he is willing to actually comply to those standards. Finally, if we who assess his belief and conduct, subscribe to those standards ourselves, then he is equally justified in claiming to be justified, if only pragmatically, to subscribe and to cling to the world-view he has been converted to. ${ }^{30}$

At first sight, Schulz' analysis of conversion to a belief in God seems to apply only to the conversion to Christianity-because in the passage that he quotes (and on which he builds his argument), Kierkegaard writes about a grasping of God with 'the category of despair', and identifies this 'category' as being "faith." Or, we know that for Kierkegaard faith is the specific way through which a person is healed of despair (the despair caused by $\sin$ ) and has access to the salvific truth of Christianity (Religion B) - the real knowledge of God (revealed in the person of Jesus Christ.)

However, as we have already seen previously, Kierkegaard defines the how of faith (the subjective truth) in this way: "An objective uncertainty, held fast through appropriation with the most passionate inwardness." 31 One might expect (given the above premises) that this definition would apply only to the Christian 
truth-the belief in the paradox of the Incarnated Christ. But this is not the case: in this passage from CUP Kierkegaard refers to the subjective truth in general (not only to the specific Christian truth); moreover, he offers as model for this faith not an authentic Christian believer (to whom the aforementioned definition would surely apply), but a "pagan" thinker: Socrates (who incarnates the immanent religious life $A$.) About Socrates Kierkegaard says that:

He stakes his whole life on this 'if'; he dares to die, and with the passion of the infinite he has so ordered his whole life that it might be acceptable-if there is immortality. Is there a better demonstration for the immortality of the soul? ${ }^{32}$

It is also relevant, in our opinion, that the aforementioned note on which H. Schulz builds his argumentation appears in the same context from $C U P$ in which the above quotation it is found. Moreover, as we know, each transition toward a "superior stage of life" (not only that from religion A to religion B) is, in Kierkegaard's view, characterized by a certain despair which is 'healed' by an adherence to the new paradigm of existence. For all these reasons we find convincing the applicability of Schulz' model to the subjective knowledge in general. ${ }^{33}$

\subsubsection{Roberts and Evans: The Normativity of Ethics as a Trigger Factor}

The second perspective on the way in which subjectivity could trigger belief in the existence of God belongs to Robert Roberts and Stephen Evans, who suggest that for Kierkegaard the consciousness of the absolute normativity of ethics (in the ethical inwardness) leads to a consciousness of God's existence. Evans and Roberts observe that, according to Kierkegaard, if we start from the premise that God created each of us in order to become selves, then our duty to become a self implies in the same time a correct relation with God. We relate correctly to God when we fulfill the duty which he gave us. In this respect, all of us receive from him the duty to actualize our ethical potentialities. Kierkegaard's ethics is for this 
reason a synthesis between the Aristotelian perspective of ethical duty understood as self-actualization, and the Kantian perspective of ethical obligation (fulfilling our ethical duty without concern for results. $)^{34}$

If Kierkegaard's ethics is partially influenced by Kant's ideas, it does not mean that he is-as moral philosopher-a representative of Enlightenment. On the contrary, as Alasdair MacIntyre suggested, Kierkegaard is the first thinker who realized the failure of Enlightenment project in its attempt of grounding ethics in human reason. ${ }^{35}$ His solution to this problem is-according to Roberts and Evans-"not to ground ethics in an act of human will, but to seek to recover divine authority as the basis for ethics." ${ }^{36}$ To Kierkegaard the only possible explanation for the constraining power of the ethical normativity is its origin in the divine authority. For him-as Roberts and Evans observe-"without the sense of being accountable or responsible to someone or something 'higher', ethical life lacks earnestness." ${ }^{37}$ In this case, the converse should also be true: if the ethical life contains earnestness, then we have the sense of being responsible to someone (or something) higher.

It is true that the modern world has developed alternatives to this idea (of grounding the ethical on divine authority.) But Kierkegaard is of the opinion that none of them is convincing. One of these alternatives is that of founding the moral obligation on the individual: this is the alternative proposed by the existentialists. A person commits herself to a self-chosen ideal, faithfully trying to fulfill it. However, for Kierkegaard such an account "cannot do justice to the actual character of the ethical life. A freely adopted ideal cannot bind if its normativity stems from the persons' choice, for such a choice can always be undone." 38 According to him: "The deficiency in the most noble human enthusiasm is that, as merely human, in the ultimate sense it is not powerful itself, because it has no higher power over itself." 39

Kant offers another alternative: he grounds the ethical normativity in human reason. Kierkegaard rejects this view in a Journal's entry:

Kant was of the opinion that man is his own law (autonomy)that is, he binds himself under the law which he himself gives 
himself. Actually, in a profounder sense, this is how lawlessness or experimentation is established. This is not being rigorously earnest any more than Sancho Panza's self-administered blows to his bottom were vigorous. ${ }^{40}$

Here the problems suggested by Kierkegaard seem to be, first of all, that of the authority of reason. Even if reason would dictate to humans how they must behave, "why should they care so much of being rational?" 41 Secondly, it seemed to many philosophers that Kant's aforementioned principle is too abstract if it wants to tell actual humans what they should do. People who conceive who they are in different ways tend to see their obligations as different. ${ }^{42}$ But "a moral obligation cannot come simply from how I think of myself, but rather it tells me how should I think about myself." 43

A third alternative is to ground the moral obligation in society. In this case the moral obligation seems to be rooted in a purported made by humans social agreement. However, Kierkegaard thinks that no such view would work, because never in the history was made such an agreement:

Should the determination of what is the law requirement perhaps be an agreement among, a common decision by, all people, to which an individual has to submit? Splendid-that is, if it is possible to find the place and fix the date for this assembling of all people ... and if it is possible, something that is equally impossible, for all of them to agree on one thing! ${ }^{44}$

In the contemporary philosophy, the idea of considering the divine authority as the basis for ethics was promoted by the Oxford philosopher RobertAdams. For Adams, "God, who is a loving personal Being, is identified with the Good, a transcendent and infinite reality. ... Moral obligations are identified with the commandments of this loving God." ${ }^{45}$

Moreover, like Kierkegaard, Adams argues that his position is superior to other alternatives from contemporary secular philosophy-like utilitarianism, expressivism or intuitionism. ${ }^{46}$

Evans observes that Adams' view, like that of Climacus, 
"is unlikely to be accepted by many contemporary secular philosophers." However, he appreciates that "there seems to be no reason in principle why a religiously grounded ethic cannot be put forward into contemporary ethical debates." ${ }^{47}$

\subsubsection{Trigger Factors: Externalist and Internalist Epistemological Justification}

We can now summarize these two perspectives regarding the triggering factor for the belief in God's existence, and draw some conclusions:

In the first perspective (of Schulz) the triggering factor is a pragmatic postulate. In this view, the awareness of the ethical imperatives comes after (or with) the postulating of the belief in God. Here the ethical stage includes belief in God.

In the second perspective (of Evans and Roberts) the triggering factor is the ethical inwardness. In this view the awareness of the ethical seems to come-at least in some cases-before the gaining of the belief in God (because it is possible for someone to gain the impression of the infinity of the ethical without a simultaneous belief in God.) Here the ethical stage does not necessary include belief in God, although it could include it. In any case, in this perspective (as in the first one too), the religious stage includes a belief in God (as we already saw the relation of the ethicist with God is rather formal than individual and personal one-because for him the demands of God are seen as general rules; his relation with God is not personal because he does not actually need God's assistance in order to fulfill his duty-in a sense, he does not need God; by contrast, one cannot imagine a religious person without a belief in God. The religious person knows that he is incapable of being what it ought to be by his own ethical effort: he knows that he needs God. For this reason, his relation with God is an attitude of personal trust in God, triggered by his experience of guilt-or eventually gratitude. $)^{48}$

The second perspective, although apparently contradictory to the first one (by saying that the ethical stage includes for some people only an awareness of God's moral imperatives and not also a 
belief in God) - is however, even if the above contradiction might be real, not a very significant contradiction. That is because the ethical stage is, in Kierkegaard thinking, a rather transitional stage from the aesthetical to the religious than a steadfast level of existence. This is because sooner or later a sincere ethicist will understand his moral bankruptcy-and if he wants to remain in this stage, he will do that only by paying the price of living in hypocrisy. In this case, if he is comfortable with this position, he only seems to live as an ethicist: in reality he lives as an esthete; hypocrisy represents an ethical stance which is self-contradictory for an ethical type of subjectivity.

In any case, the two aforementioned perspectives have one essential thing in common: either from pragmatical reasons, or from ethical reasons (or maybe from both pragmatical and ethical reasons), the people arrive in the end to a belief in a personal (theistic) God. These reasons trigger in them the subjective knowledge that God exists, and thus, through this kind of pragmatic and/or ethical recollection, they arrive to a belief in the existence of God-a knowledge which any of us seem to possess apriori, in a more or less conscious way.

In addition to that, one might observe that this process of transition from non-belief to belief in God is in both cases rationally justified. In the first perspective (the Schulzian) we have a pragmatic type of justification: it is rational to believe in God because this belief helps the believer in defeating despair. Of course, this pragmatic justification offers no warranty that the object of belief-God, in our case-is real (and not rather a fiction produced by our human psychological needs - a type of Freudian 'heavenly father'.) If we keep here in mind only the individual's internal point of view, there are few chances to have contact with a true reality at the end of our pragmatic reasoning. In this case, the observation that an internalist epistemology ${ }^{49}$ is never able to offer access toward truth is fully applicable. As John Greco suggested, truth is by definition a feature external to our epistemic access - truth belongs to the externalist epistemology. ${ }^{50}$

On the other side, if God is real, and he created us as beings capable of finding relief from their existential despair only when 
postulating his existence, then we are also justified in believing that our pragmatic postulate will lead us to truth. An externalist epistemology might offer o real solution in this respect, because it says, as for example Alvin Plantinga's externalist model suggest, that a belief can be warranted if it is gained by a reliable process, according to a design plan aimed at producing true beliefs. ${ }^{51}$ In our case, God could have created us in such a way as to achieve belief in him by this kind of pragmatic (but also reliable) process of postulating him when seeking relief from our despair. It is true that such an externalist epistemological solution does not offer Cartesian certainty to our knowledge. Plantinga's agrees that we may sometimes think we know something when in fact we do not, and conversely, that we may sometimes know something without being able to offer (all) evidences for this knowledge (in other words, we might know something without knowing that we know it.) But that is for us just another argument for the idea that an externalist, in opposition to the internalist (who in essence remains a disciple of Descartes), "has a more robust sense of our human finitude," 52 being in this respect adept of a more modest kind of epistemology.

In the second perspective, God is an explanation for the awareness of the earnestness from our ethical norms. Again, it is rational to believe in God because this belief helps us to explain the earnestness of the ethical experience. In this case, however, we have an explanatory rather than a pragmatic type of justification. The reasoning seems a kind of implicit moral argument for the existence of God-in spite of the fact that in principle Kiekegaard opposed any arguments for God's existence.

However, the explanation is not equivalent with a type of positive abduction, but rather with a kind of Popperian hypothesis (one which resisted all the attempts of falsifying it.) This is the case because, as Philip Quinn has argued, on the one side the idea of divine authority as the basis for ethics could not be (at least until now) refuted (in spite of all the efforts of the skeptic moral philosophers), though on the other side it could also find (at least not until now) any strong positive confirmation too. ${ }^{53}$ 
But it is also true that Adams observation that God's hypothesis seems to be the best explanation for the fact that the moral facts are perceived as objective (their validity does not depend on what the humans think about them) and non-natural (they cannot be stated entirely in the language of science) might suggest a certain abductive dimension to the moral argument for God's existence. ${ }^{54}$

It seems to us for this reason that this second perspective has some internalist justification-in contrast to the first one. But because, in the same Popperian vein, we cannot apriori exclude the idea that someone might find a refutation to it-and thus that its internalist confirmation remains imperfect-we can say that even in this case an externalist appeal to the hypothesis of God as the Creator of our beings remains the best argument for the warrant of the aforementioned belief. God might have created us in such a way that we-when realizing the infinity of the ethical in our livesshould start believing in him.

Arguments for this externalist type of warrant (for our belief in God) in Kierkegaard's writings could be seen at least in two quotations. In the first one (from his journal) this idea it is implicitly stated:

In all the usual talk that Johannes Climacus is mere subjectivity, etc., it has been completely overlooked that in addition to all his other concretions he points out in one of the last sections that the remarkable thing is that there is a How with the characteristic that when the How is scrupulously rendered the What is also given, that this is the How of faith. Right here, at its very maximum, inwardness is shown to be objectivity. ${ }^{55}$

In the second one (from his Christian Discourses), this idea it is stated explicitly:

But truly, just as little as God lets a species of fish grow in a particular lake unless the plant also grows there which is its nutriment, just so little shall God leave in ignorance of what he must believe the person who is truly concerned.... The thing sought is in the seeking that seeks it, faith in the concern at not having faith, love, in the concern at not loving. 
... The need brings with it the nutriment ... not by itself ... but by virtue of God's providence. ${ }^{56}$

In conclusion to what we discussed until now, we might say that according to Kierkegaard each person seems to have a kind a "sensus divinitatis" of which she becomes aware through a recollection mediated by her moral experience and/or by the pragmatical necessity of seeking relief from her existential despair.

\section{Conclusion: Desirable Consequences of the Idea of "Inwardly Conditioned" Religious Knowledge}

At the end of this essay we would like to present some positive consequences of the fact that religious knowledge is mediated by inwardness. Evans argued that if God existed, then this way of arriving to know him is to be expected-due to the desirable effects

of this inwardly mediated path. Among these positive effects Evans enunciates these:

1. "If the knowledge of God is conditioned by inwardness, human freedom is protected." A loving God would like that human beings should obey him freely - but if the human beings would see his presence too obvious, they would be inclined to obey him just for self-protective reasons, even if they don't really like him. ${ }^{57}$

2. If the knowledge of God is inwardly conditioned, then the human equality will always be protected. For Kierkegaard, God is always impartial ${ }^{58}$. If the knowledge of God would be mediated by our intellectual acuity, or education, or possessions, etc, this principle would be violated-because in respect to all these things people are very different.

3. "If the knowledge of God is conditioned by inwardness, then the process of coming to know God will be a process in which the individual is spiritually developed." 59 In coming to know God, the individual will be more authentic and will spiritually grow.

4. "If the knowledge of God is conditioned by inwardness, then it is ensured that the person who becomes aware of God becomes (also) aware of God's true nature." ${ }^{60}$ Only the person 
who comprehends such inward passions as guilt, repentance and gratitude would be able to grasp such divine qualities as "the one who offers forgiveness," "the one who empowers the individual to make a new beginning" and "the gracious giver of every good gift." ${ }^{61}$ In this respect Silvia Walsh observed also that for Kierkegaard:

the way to go about forming a true conception of God is by turning inward, where one comes to know God not as an external object but 'more intimately' or personally as a transcendent subject to whom one must be related in absolute devotion or else not at all. ${ }^{62}$

These aforementioned consequences are another argument for the plausibility of Kierkegaard's account of religious knowledge. Moreover, if the knowledge of the existence (and of at least some attributes) of God depends on our moral experience and on our existential experience of despair-being ultimately related to God himself (who eventually made us in such a way as to react to these experiences with faith) -then the future cannot deteriorate this knowledge. We believe that, if Kierkegaard's view on this subject is true, the humans will continue to believe in God (and to have a certain knowledge of him) even in a future modeled by the present scientific, high-tech and multicultural revolution.

NOTES

${ }^{1}$ Hermann Deuser, "Kierkegaards Verteidigung der Kontingenz: <Daß etwas Inkommensurables in einem Menschenleben ist>," Kierkegaardiana 15 (1991): 104.

${ }^{2}$ Marilyn Piety, Ways of Knowing: Kierkegaard's Pluralist Epistemology (Waco, TX: Baylor University Press, 2010), 117; See also the famous quotation from Søren Kierkegaard, The Sicknss into Death (Princeton: Princeton University Press, 1980) 13-14, in which "the other"-who is God-is essential for the constituency of the self, in Kierkegaard's view: he is the creator of the self and its point of reference.

3 Søren Kierkegaard, Concluding Unscientific Postscript (Princeton: Princeton University Press, 1992), 545. 
4 Søren Kierkegaard, Philosophical Fragments (Princeton: Princeton University Press, 1985), 87.

${ }^{5}$ See in this respect Piety, Ways of Knowing, 118 and Søren Kierkegaard, Journals and Papers (Bloomington: Indiana University Press, 1967), 3.662. However, it is interesting that later in his Journal he retracts the phrase "I do not believe that God exists, but I know it" - suggesting that it is too strong; he explains that he put together these two propositions only in order to contrast them. He asserts now that "even from the Greek point of view the eternal truth, by being for an existing person, becomes an object of faith and a paradox"adding that this kind of Greek Socratic faith is different from the Christian faith (Kierkegaard, Journals and Papers, 3.404.)

${ }^{6}$ See again the following passage from the same paragraph from $J P$ quoted in the note 15: ". . there has never been an atheist even though certainly have been many who have been unwilling to let what they know to (that the god exists) get control of their minds. It is the same as with immortality. Suppose someone became immortal by means of another demonstrating it-would that not been infinitely ridiculous? Therefore there has never been a man who has not believed it, but there certainly have been many who have been unwilling to let the truth conquer in their souls, have been loathe to allow themselves to be convinced, for what convinces me exists, but the important thing is that I become immersed in it" (Kierkegaard, Journals and Papers, 3.662.)

${ }^{7}$ David Roberts, Kierkegaard's Analysis of Radical Evil (London and New York: Continuum, 2006.)

${ }^{8}$ Kierkegaard, Journals and Papers, 197; Kierkegaard, Journals and Papers, 2281.

${ }^{9}$ Piety, Ways of Knowing, 116, 128.

${ }^{10} \mathrm{~J}$. A. Di Noia, "Religion and religions," in The Cambridge Companion to Karl Barth, ed. John Webster (Cambridge: Cambridge University Press, 2000), 246.

${ }^{11}$ Ibid., 119.

${ }^{12}$ Ibid., 120.

13 Ibid., 121; Søren Kierkegaard, "Judge for Yourself!," in For SelfExamination and Judge for Yourself (Princeton: Princeton University Press, 1990), 117.

${ }^{14}$ Piety, Ways of Knowing, 124.

${ }^{15}$ Stephen Evans, Kierkegaard's ethic of love (New York: Oxford University Press, 2004), 49.

${ }^{16}$ Piety, Ways of Knowing, 120.

${ }^{17}$ Evans, Kierkegaard's ethic of love, 49; John Hare, The Moral Gap: Kantian Ethics and God's Assistance (Oxford: Oxford University Press), 1996.

18 Søren Kierkegaard, Fear and Trembling (Princeton, NJ: Princeton University Press, 1983), 68.

${ }^{19}$ Kierkegaard, Fear and Trembling, 70.

${ }^{20}$ Evans, Kierkegaard's ethic of love, 50. 
${ }^{21}$ Ibid., 88.

${ }^{22}$ Alastair Hannay understands inwardness as "a mental state involving some form of conflict", when the believer (in the inwardness of faith) "fasten on to what he wants, in spite of the uncertainty that he will get it." (Alastair Hannay, Kierkegaard: The Arguments of the Philosophers (London and New York: Routledge, 1999), 126.) On the other side Evans sees the concept of inwardness as covering a larger area than that of the specific religious faith. He equates "inwardness" with "subjectivity": here the individual develops passionsunderstood as enduring emotions that give shape and direction to his life, for goals which are eternal. In this case, inwardness (and subjectivity) is defined as "the affective dimension of human life that must take center stage if we are to understand human existence" (Stephen Evans, Kierkegaard: An Introduction (Cambridge: Cambridge University Press, 2009), 19-22, 34, 35.) In Evans' case inwardness has something to do also with the ethical (not just with the religious): in inwardness the ethical ideals become part of the life of the ethicist.

${ }^{23}$ Kierkegaard, Concluding Unscientific Postscript, 243-244.

${ }^{24}$ Ibid., 138.

${ }^{25}$ Merold Westphal, Becoming a Self: A reading of Kierkegaard's Concluding Unscientific Postscript (West Lafayette, IN: Purdue University Press, 1996), 105.

${ }^{26}$ Evans, Kierkegaard's ethic of love, 88.

${ }^{27}$ Piety, Ways of Knowing, 120.

28 Heiko Schulz, "Conversion, truth and rationality," in Conversion: Claremont Studies in the Philosophy of Religion, Conference 2011, ed. Ingolf Dalferth et al. (Tübingen: Mohr Siebeck, 2013), 191.

${ }^{29}$ Kierkegaard, Concluding Unscientific Postscript, 200, note.

${ }^{30}$ Schulz, "Conversion, truth and rationality," 193.

${ }^{31}$ Kierkegaard, Concluding Unscientific Postscript, 203.

${ }^{32}$ Kierkegaard, Concluding Unscientific Postscript, 201; see also Westphal, Becoming a Self, 120-121.

${ }^{33}$ What is not very clear to us, however, in H. Schulz model, is the measure in which the crisis of the aesthete would necessary trigger, in the transition toward the ethical stage, a postulating of God rather than just a postulating of some platonic ethical norms (and nothing more.) However, it seems to us that the ethical stage is not a very stable stage-but rather a transitory one toward the religious stage. All ethicists will know after less or more time that they cannot fulfill their ethical duties. When they realize this, they can no more remain in the ethical stage without living in hypocrisy; but hypocrisy is a killer for subjective knowledge (and inwardness) in general.

${ }^{34}$ Evans, Kierkegaard's ethic of love, 90.

${ }^{35}$ Alasdair MacIntyre, "Excerpt from After Virtue," in Kierkegaard After MacIntyre: Essays on Freedom, Narrative and Virtue, ed. by John Davenport et al. (Chicago: Carus Publishing Company, 2001), xxxv. 
${ }^{36}$ Robert C. Roberts and Stephen Evans, "Ethics," in The Oxford Handbook of Kierkegaard, ed. by John Lippitt et al. (Oxford: Oxford University Press, 2013), 215.

${ }^{37}$ Roberts and Evans, “Ethics," 216.

${ }^{38}$ Ibid., 216.

${ }^{39}$ Søren Kierkegaard, Works of Love (Princeton: Princeton University Press, 1995), 190.

${ }^{40}$ Kierkegaard, Journals and Papers, 188.

${ }^{41}$ Roberts and Evans, "Ethics," 216.

${ }^{42}$ Ibid., 217.

${ }^{43}$ Ibid., 217.

${ }^{44}$ Kierkegaard, Works of Love, 115.

${ }^{45}$ Evans, Kierkegaard's ethic of love, 90-91.

${ }^{46}$ Robert Adams, "Moral Arguments for Theistic Belief," in God, ed. by Timothy Robinson (Indianapolis, IN: Hackett Publishing Company, Inc, 2002), 90-112; Evans, Kierkegaard's ethic of love, 91.

${ }^{47}$ Evans, Kierkegaard's ethic of love, 91; Philip Quinn suggested that divine command ethics has experienced recently a revival: the supporters of this approach have successfully rejected all the objections of their opponents. However, to him this theory needs also a positive argument. He tries to offer such an argument in the local and limited field of theology (see Philip Quinn, "The recent Revival of Divine Command Ethics," Philosophy and Phenomenological Research 50, Supplement (Autumn 1990): 345-365.)

${ }^{48}$ Stephen Evans, "Kierkegaard and Plantinga on Belief in God: Subjectivity as the Ground of Properly Basic Religious Beliefs," in Stephen Evans, Kierkegaard on Faith and the Self: Collected Essays (Waco, TX: Baylor University Press, 2006), 179.

49 Internalism in epistemology is a view about cognitive accessibility according to which what confers warrant to a belief 'must be accessible, in some special way', to us. Conversely, externalism is the view that what confers warrant to a belief is not accessible to us, at least not in a certain measure.

${ }^{50}$ John Greco, "Justification Is not Internal," in Contemporary Debates in Epistemology, ed. by Mattias Steup et al. (Oxford: Blackwell Publishing, 2005), 257-269

${ }^{51}$ Alvin Plantinga, Warrant and Proper Function, (Oxford: Oxford University Press, 1993), 19.

${ }^{52}$ Stephen Evans, "Externalist Epistemology, Subjectivity, and Christian Knowledge," in Stephen Evans, Kierkegaard on Faith and the Self: Collected Essays) (Waco, TX: Baylor University Press, 2006), 189.

${ }^{53}$ Quinn, "The recent Revival of Divine Command Ethics," 345-365.

${ }^{54}$ Adams, "Moral Arguments for Theistic Belief," 116-140.

${ }^{55}$ Kierkegaard, Journals and Papers, 4550.

${ }^{56}$ Søren Kierkegaard, Christian Discourses and The Crisis and a Crisis in the Life of an Actress (Princeton: Princeton University Press, 1995), 244-245. 
${ }^{57}$ Evans, "Kierkegaard and Plantinga on Belief in God," 180.

${ }^{58}$ Westphal, Becoming a Self, 107, 128; Evans, "Kierkegaard and Plantinga on Belief in God," 180.

${ }^{59}$ Evans, "Kierkegaard and Plantinga on Belief in God," 180.

${ }^{60}$ Ibid., 180.

${ }^{61}$ Ibid., 180.

${ }^{62}$ Silvia Walsh, "Kierkegaard's Theology," in The Oxford Handbook of Kierkegaard, ed. by John Lippitt et al. (Oxford: Oxford University Press, 2013), 295.

\section{BIBLIOGRAPHY}

Adams, Robert. "Moral Arguments for Theistic Belief." In God, edited by Timothy Robinson, 90-112. Indianapolis, IN: Hackett Publishing Company, Inc, 2002.

Deuser, Hermann. "Kierkegaards Verteidigung der Kontingenz: $<$ Daß etwas Inkommensurables in einem Menschenleben ist>." Kierkegaardiana 15 (1991): 104-116.

Di Noia, J. A., "Religion and religions." In The Cambridge Companion to Karl Barth, edited by John Webster, 243-257. Cambridge: Cambridge University Press, 2000.

Evans, Stephen. Kierkegaard on Faith and the Self: Collected Essays. Waco, TX: Baylor University Press, 2006.

Evans, Stephen. Kierkegaard: An Introduction. Cambridge: Cambridge University Press, 2009.

Evans, Stephen. Kierkegaard's ethic of love. New York: Oxford University Press, 2004.

Greco, John. "Justification Is not Internal." In Contemporary Debates in Epistemology, edited by Mattias Steup and Ernest Sosa, 257-269. Oxford: Blackwell Publishing, 2005.

Hannay, Alastair. Kierkegaard: The Arguments of the Philosophers. London and New York: Routledge, 1999.

Kierkegaard, Søren. Christian Discourses and The Crisis and a Crisis in the Life of an Actress. Princeton: Princeton University Press, 1995.

Kierkegaard, Søren. Concluding Unscientific Postscript. Princeton: Princeton University Press, 1992.

Kierkegaard, Søren. Fear and Trembling. Princeton, NJ: Princeton University Press, 1983.

Kierkegaard, Søren. Journals and Papers. Bloomington: Indiana University Press, 1967.

Kierkegaard, Søren. Philosophical Fragments. Princeton: Princeton University Press, 1985. 
Kierkegaard, Søren. The Sicknss into Death. Princeton: Princeton University Press, 1980. 1995.

Kierkegaard, Søren. Works of Love. Princeton: Princeton University Press,

MacIntyre, Alasdair. "Excerpt from After Virtue." In Kierkegaard After MacIntyre: Essays on Freedom, Narrative and Virtue, edited by John Davenport and Anthony Rudd, xxxv. Chicago: Carus Publishing Company, 2001.

Piety, Marilyn. Ways of Knowing: Kierkegaard's Pluralist Epistemology. Waco, TX: Baylor University Press, 2010.

Plantinga, Alvin. Warrant and Proper Function. Oxford: Oxford University Press, 1993.

Quinn, Philip. "The recent Revival of Divine Command Ethics." Philosophy and Phenomenological Research 50, Supplement (Autumn 1990): 345-365.

Roberts, David. Kierkegaard's Analysis of Radical Evil. London and New York: Continuum, 2006.

Roberts, C. Robert and Evans, Stephen. "Ethics." In The Oxford Handbook of Kierkegaard, edited by John Lippitt and George Pattison, 211-229. Oxford: Oxford University Press, 2013.

Schulz, Heiko. "Conversion, truth and rationality." In Conversion: Claremont Studies in the Philosophy of Religion, Conference 2011, edited by Ingolf Dalferth and Michael Rodgers, 179-203. Tübingen: Mohr Siebeck, 2013.

Walsh, Silvia, "Kierkegaard's Theology." In The Oxford Handbook of Kierkegaard, edited by John Lippitt and George Pattison, 292-308. Oxford: Oxford University Press, 2013.

Westphal, Merold. Becoming a Self: A reading of Kierkegaard's Concluding Unscientific Postscript. West Lafayette, IN: Purdue University Press, 1996. 